\title{
TAL AV REPUBLIKENS PRESIDENT TARJA HALONEN VID NOR- DISKA KRIMINALISTMÖTET VID HELSINGFORS UNIVERSITET DEN 10.6.2004
}

För nästan fyrtio år sedan fick jag som ung juridikstuderande av professor Inkeri Anttila ett tema för min avhandling som gällde fostran och skyddande av unga förbrytare på anstalt och i frihet. Under licentiatseminariet tänkte jag sedan fortsätta att forska kring samma tema. Men allt slags världsförbättrande kom emellan, och professor Anttila frågade mig sedan om inte detta goda ämne kunde ges till någon annan forskare. Och det gjorde vi. Jag vill minnas att jag försvarade mig med att svaren på de frågor ämnet berörde bättre hittas någon annanstans än inom juridiken. Och på den vägen är vi fortfarande, även om betydelsen av straffrätt och god kriminalpolitik hunnit klarna många gånger om.

Kriminalpolitiken syftar till att påverka brottsligheten. Den hårda kärnan i kriminalpolitiken är straffrättssystemet; strafflagstiftningen och tillämpningen av den i praktiken. Straffrättens medel är dock begränsade. Till kriminalpolitik i ordets vida bemärkelse hör också mycket annat. Det är befogat att i det avseendet söka efter svar "någon annanstans", t.ex. inom socialpolitiken.

Bäst har kriminalpolitiken lyckats när man kunnat förebygga brott. Ett sådant förebyggande är också målet med själva straffrättssystemet. Genom straffhot i lagen och bestraffning av utförda brott eftersträvas allmänpreventiv och specialpreventiv verkan. På sistone har man återigen också i Norden lyft fram förebyggandet av brott $\mathrm{i}$ en vidare bemärkelse. I samhällsplaneringen och allt samhälleligt beslutsfattande borde beslutens effekter på brottstillfällena även beaktas.

Straffrätt har av tradition ansetts vara ett rättsområde som är markerat nationellt. Den historiska utgångspunkten för internationell rätt är varje stats suveränitet inom sitt eget område. Strafflagstiftningen och den straffrättsliga rättsvården har ansetts höra till kärnområdet för en stats suveränitet.

Den internationella gemenskapen har småningom bearbetat suveränitetstänkandet inom den internationella rätten. Att motarbeta internationella brott och ställa förbrytarna till svars är i princip i alla staters intresse. Den internationella gemenskapen ger nuförtiden straffrätten en viktig roll i fråga om internationell rättvisa, de mänskliga rättigheterna och världsfreden. Internationalisering hör till de dominerande utvecklingstrenderna också inom straffrätten.

Det finns flera orsaker till internationaliseringsutvecklingen och behovet av gemensamma regler. De kommer till uttryck på olika sätt: större oro och ansvar för vår gemensamma planets öde, ett spirande intresse för internationell rättvisa och rätt och slätt ökad internationell handel och annat umgänge. 
Människans ökade rörlighet över statsgränserna, också inom Norden eller Europeiska unionen, har medfört ett större behov av internationell samverkan också i brottmålsfrågor. Vissa typer av brott, såsom människohandel och omfattande narkotikahandel, är redan till sin grundläggande natur fenomen som överskrider de nationella gränserna. Samma gäller till stor del internationell terrorism.

Det finns också brott som så djupt kränker hela mänsklighetens viktigaste grundläggande värderingar att en bekämpning och bestraffning av dem inte kan överlåtas på enskilda stater, utan de kräver en gemensam insats av hela den internationella gemenskapen.

En viktig milstolpe i straffrättens historia var i detta hänseende att Internationella brottsmålsdomstolen (ICC) inrättades. Till ICC:s jurisdiktion hör folkmord, brott mot mänskligheten och krigsförbrytelser. Avsikten är att också angreppsbrott ska innefattas i Internationella brottsmålsdomstolens domsrätt. Det är beklagligt att vissa centrala stater, bland dem Förenta Staterna, hittills inte erkänt Internationella brottsmålsdomstolens domsrätt.

Det är mer än tio år sedan det kalla krigets slut. Utvecklingen efter det har varit tudelad. Europa har integrerats och demokratiserats, vilket medfört rättvisare och öppnare samhällen. Risken för ett konventionellt krig har minskat i Europa, men samtidigt har vi tvingats bevittna interna krig inom stater, krigsförbrytelser och brott mot mänskligheten. Såväl i Europa som annorstädes i världen är de huvudsakliga offren för väpnade konflikter civilpersoner och inte arméer.

Om redan de rent straffrättsliga medlen vid bekämpning av sedvanlig brottslighet är begränsade, borde man inte heller av den internationella straffrätten vänta sig några under när det gäller att bekämpa och reagera på de allvarligaste tänkbara brotten. Men lika lite som någon på nationell nivå föreslår att straffrätten skall avskaffas för att den är bristfällig, finns det heller något skäl att förringa betydelsen av den internationella straffrätten och Internationella brottsmålsdomstolen. Tvärtom är det viktigt att på allt sätt stödja den verksamheten.

Terrorism har åtminstone sedan den 11. september 2001 varit en av den internationella straffrättens centrala frågor. Också de nordiska länderna har tvingats se över sin strafflagstiftning på det sätt som de internationella förpliktelserna gällande terrorism förutsätter. Bekämpningen av terrorism kräver strama straffrättsliga medel, samtidigt som de metoder som används skall vara värdiga den demokrati som försvaras. I syfte att nå ett hållbart resultat måste våra åtgärder dessutom också sträcka sig till de orsaker som ligger bakom terrorismen. Terrorism, som ni valt som ett teman för ert möte, är ett viktigt och intressant, men också ett ytterst svårt ämne. 
Samhället förändras och som ett led i denna förändring blir vissa nya gärningar straffbara medan tidigare brott avkriminaliseras. Homosexualitet var i Finland fram till 1970-talet ett brott. Att aga barn i uppfostringssyfte är numera straffbart och hela familjevåldskomplexet har med nytt allvar lyfts fram inom straffrätten. Ett annat tema för ert möte är människohandel och prostitution i samband med sexhandel. Ämnet är än en gång synnerligen viktigt och aktuellt. Lagstiftningen om prostitution lindrades under de föregående decennierna. Men så sent som $i$ början av denna vecka godkände Finlands riksdag ändringar i vår strafflag genom vilka vi effektivare än tidigare kan bekämpa människohandel, koppleri och prostitution.

Människohandel och prostitution, med alla därtill hörande fenomen, är vardag för tusentals kvinnor i Europa - för att inte tala om andra världsdelar. Jag sätter stort värde på att den internationella gemenskapen - Förenta Nationerna, Internationella arbetsorganisationen, Europarådet och Europeiska unionen - har kunnat enas om nödvändigheten av internationella avtal och andra rättsinstrument.

Det är nödvändigt med straffrättsliga medel för att bekämpa dessa gärningar, som grovt kränker de mänskliga rättigheterna. Men också i detta sammanhang bör man komma ihåg att gärningarna inte upphör $\mathrm{i}$ och med att de görs straffbara. Utöver användningen av straffrättsliga medel borde man kunna påverka själva orsakerna bakom människohandel och prostitution. Prostitution är ofta en följd av ekonomisk ojämlikhet både i vårt eget land och i våra närområden.

Vår värld saknar till exempel ett globalt internationellt avtal om människors rörlighet över gränserna, i vilket ursprungslandets, mottagarlandets och själva människornas rättigheter kunde beaktas. Laglig invandring eller migration kunde vara en dellösning då det gäller människohandel och prostitution. Många kvinnor har fallit offer för prostitution och koppleri när de med olagliga medel försökt ta sig in på en laglig arbetsmarknad i ett annat land. Jag vill i detta sammanhang fästa uppmärksamhet vid Sveriges och Schweiz aktiva roll när det gäller att få till stånd internationella bestämmelser om migration.

Europeiska unionen är en allt viktigare aktör också på det straffrättsliga området. Om det utkast till grundlag för EU som för tillfället bereds av regeringskonferensen godkänns, innebär det betydande förändringar i det straffrättsliga samarbetet inom EU. Det är svårt att bedöma hur snabb utvecklingen kommer att vara, men harmoniseringen av straffrätten torde fortgå. Det finns förståeliga skäl för det. Inte ens en positiv utveckling har varit problemfri för de nordiska länder som är medlemmar i EU. Brottslighetsproblemen varierar mycket inom de olika EU-medlemsländerna, liksom också de traditioner som hänför sig till strafflagstiftningen och rättsvården på straffrättens område. Ett konkret exempel är de 
minimi- och maximistraff som fastställs i EU:s rambeslut och som avviker från straffskalan i den nationella lagstiftningen.

Alla medlemsländer har fulla befogenheter att påverka också den straffrättsliga utvecklingen inom EU. På den punkten borde de nordiska länderna vara aktiva. Som lösning på många problem tycks man inom EU erbjuda straffrättsliga medel: kriminalisering och stränga straffhot. Den naturliga utgångspunkten verkar inte vara att tänka på straffrätten som ultima ratio, en sista utväg för att lösa problem. Tanken på en vittsyftande kriminalpolitik, god socialpolitik och ett välfärdssamhälle som bästa medel för att på sikt råda bot också på brottslighetsproblem, vore en önskvärd importvara.

Bästa deltagare i det nordiska kriminalistmötet,

Dessa möten har en värdefull tradition. Håll fast vid den och var stolta över resultaten. Det känns tryggt att delta i nordiskt samarbete inom straffrätt och kriminalpolitik. Finland är ett gott exempel på ett land som av historiska orsaker haft stor nytta av detta samarbete och som förhoppningsvis också kunnat bidra till det med egna insatser.

Det nordiska kriminalistmötet är värdefullt också därför att det samlar alla nordiska länder, både de som hör till EU och de som står utanför. Kunskap sprids och i den snabba integrationsprocessen inom EU gör det gott att stanna upp och dryfta saker ur ett nordiskt perspektiv. Inom straffrätten och kriminalpolitiken har kontakten och samarbetet mellan våra länder av tradition och också i internationell jämförelse präglats av exceptionell smidighet och ömsesidigt förtroende.

Jag önskar er ett framgångsrikt möte och intressanta diskussioner. 